\title{
NEW DIRECTION IN HUMAN COLONISATION OF THE PACIFIC: Lapita Settlement of South Coast New Guinea
}

Ian J. McNiven ${ }^{1}$, Bruno David ${ }^{1}$, Thomas Richards ${ }^{1}$, Ken Aplin ${ }^{2}$, Brit Asmussen ${ }^{3}$, Jerome Mialanes ${ }^{1}$, Matthew Leavesley ${ }^{4}$, Patrick Faulkner ${ }^{5}$ and Sean Ulm ${ }^{6}$

\begin{abstract}
Expansion of Austronesianspeaking peoples from the Bismarck Archipelago out into the Pacific commencing c.3300 cal BP represents the last great chapter of human global colonisation. The earliest migrants were bearers of finelymade dentate-stamped Lapita pottery, hitherto found only across Island Melanesia and western Polynesia. We document the first known occurrence of Lapita peoples on the New Guinea mainland. The new Lapita sites date from 2900 to $2500 \mathrm{cal}$ BP and represent a newly-discovered migratory arm of Lapita expansions that moved westwards along the southern New Guinea coast towards Australia. These marine specialists ate shellfish, fish and marine turtles along the Papua New Guinea mainland coast, reflecting subsistence continuities with local pre-Lapita peoples dating back to $4200 \mathrm{cal}$ BP. Lapita artefacts include characteristic ceramics, shell armbands, stone adzes and obsidian tools. Our Lapita discoveries support hypotheses for the migration of pottery-bearing Melanesian marine specialists into Torres Strait of northeast Australia c. 2500 cal BP.
\end{abstract}

\section{Introduction}

Around 3300 cal BP a distinctive type of pottery with finelyexecuted dentate-stamped designs and labelled 'Lapita' arose in the Bismarck Archipelago of northeastern Papua New Guinea and continued in various forms through to sometime between 2600 and $2200 \mathrm{cal} \mathrm{BP}$ (Summerhayes 2007, 2010a, 2010b:95). Soon after its development, bearers of this pottery began migrating eastwards to commence the great $4500 \mathrm{~km}$-long colonisation process of

School of Geography and Environmental Science, Monash University, Clayton, VIC 3800, Australia ian.mcniven@monash. edu, bruno.david@monash.edu, thomas.richards@monash.edu, jerome.mialanes@monash.edu

2 Australian National Wildlife Collection, CSIRO Division of Ecosystem Sciences, PO Box 284, Canberra, ACT 2601, Australia aplin.ken@ csiro.au

${ }^{3}$ Queensland Museum, PO Box 3300, South Brisbane, QLD 4101, Australia brit.asmussen@qm.qld.gov.au

${ }^{4}$ Anthropology, University of Papua New Guinea, PO Box 320, University PO NCD, Papua New Guinea matthew.leavesley@gmail. com

${ }^{5}$ School of Social Science, The University of Queensland, Brisbane, QLD, 4072 Australia p.faulkner@uq.edu.au

${ }^{6}$ Department of Anthropology, Archaeology and Sociology, School of Arts and Social Sciences, James Cook University, PO Box 6811, Cairns, QLD 4870, Australia sean.ulm@jcu.edu.au the Pacific. East of the Bismarcks, Lapita colonisers have been documented in Remote Oceania in the Reef/Santa Cruz Islands (c.3200 cal BP) (Green et al. 2008), Vanuatu, New Caledonia and Fiji (c.3000 cal BP) (Bedford et al. 2006; Clark and Anderson 2009:175), Tonga (c.2900 cal BP) (Burley and Connaughton 2007) and Samoa (c.2700 cal BP) (Rieth et al. 2008) (Figure 1). Despite the status of Papua New Guinea (specifically the Bismarck Archipelago) as the homeland of Lapita pottery, no Lapita sites have been documented on the New Guinea mainland and the landmass appeared to have been 'avoided by Lapita makers and users' (Lilley 2008:79). The earliest mainland pottery documented was the first phase of the Early Papuan Pottery tradition (EPP) dated to $2000 \mathrm{cal}$ BP on the south coast of Papua New Guinea (Summerhayes and Allen 2007). However, red-slipped pottery dating to c. $2500 \mathrm{cal}$ BP in Torres Strait adjacent to the central south coast of New Guinea, and made with tempers consistent with local geological sources, was hypothesised to have been made locally by peoples with ancestral connections to pottery-making peoples of the Gulf of Papua (McNiven et al. 2006). A major implication of this hypothesis was that pottery along the south coast of Papua New Guinea must date to earlier than $2000 \mathrm{cal}$ BP, and thus at least 500 years older than the earliest known ceramics from the south coast of Papua New Guinea, with deeper ancestral connections back to Lapita peoples of the Bismarck Archipelago. Recent discoveries of undecorated pottery dating to 2300-2800 cal $\mathrm{BP}$ on Wari Island off the far southeast corner of mainland Papua New Guinea gave partial support to this hypothesis (Negishi and Ono 2009).

In 2009-2010, we excavated nine sites with Lapita pottery at Caution Bay located 20km northwest of Port Moresby, southern Papua New Guinea (Figure 1). Here Lapita pottery first appears $2900 \mathrm{cal}$ BP with pre-ceramic occupation extending back to at 


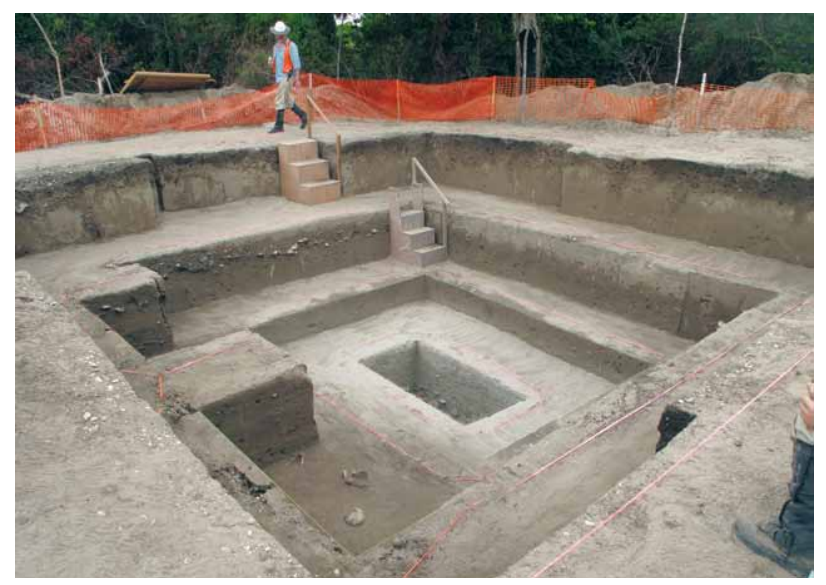

Figure 2 Bogi 1 during excavation, March 2010. The dense layer of shell midden deposit exposed in the section next to the lower set of steps dates to 2600-2900 cal BP and contains the deepest and oldest Lapita pottery in the site. Partly excavated pre-Lapita burial (bottom left-hand corner of the excavation pit) (Photograph: Rob Skelly).

least $4200 \mathrm{cal} \mathrm{BP}$ and what is the earliest known evidence for human settlement of the south coast of New Guinea.

\section{Caution Bay Lapita Sites}

The Lapita sites are located within an area extending $6.5 \mathrm{~km}$ along the coast and up to $1.75 \mathrm{~km}$ inland. This makes Caution Bay the largest contiguous Lapita landscape found anywhere in the Pacific. Sites occur along a linear sand spit backing the shoreline (sites Bogi 1, JD17, JD6, JD10 and JD14) and on low grassy hills with clay sediments (sites JA1, RS63, Moiapu 1 and Edubu 1). Initial AMS radiocarbon dating indicates that at least two of the frontal dune sites (Bogi 1 and JD6) were occupied intermittently for the past 4200 years. Other sites (e.g. Edubu 1, Moiapu 1) reveal shorter-term occupation. We present major finds from these sites and demonstrate that together they conform to key markers of the 'Lapita cultural complex' (Green 1979:31; Kirch 1997; Spriggs 1997). In addition, we illustrate the high stratigraphic integrity of sites with the long-term sequence at Bogi 1. Here, as at all sites, fine-grained excavations were undertaken using $2-3 \mathrm{~cm}$ thick Excavation Units (XUs) following the stratigraphy to allow detailed analyses and high resolution understandings of depositional history and cultural change. Charcoal samples for radiocarbon dating and significant cultural materials (e.g. decorated sherds) were plotted in three dimensions. Excavated sediments were wet sieved through $2.1 \mathrm{~mm}$ mesh.

\section{Bogi 1 Stratigraphy and Chronology}

An $8 \mathrm{~m} \mathrm{x} 9 \mathrm{~m}$ pit divided into $1 \mathrm{~m} \times 1 \mathrm{~m}$ squares was excavated at Bogi 1 to a depth of $3.5 \mathrm{~m}$ in central Squares C and D (Figure 2). Sediments are mostly aeolian dune sands. Stratigraphic Units (SUs) were differentiated by changes in sediment texture and colour and the density of midden deposits (Figure 3). Cultural materials such as stone artefacts, charcoal, shells and animal bones occur in varying densities from the ground surface to a depth of at least $2.5 \mathrm{~m}$. Below $2.0 \mathrm{~m}$, calcium carbonate concretions increase in density with a zone of cemented sediments located $3.0-3.3 \mathrm{~m}$ below the surface.

Twenty-four AMS radiocarbon dates on single fragments of charcoal are available for Squares C and D (Table 1, Figure 4). The single anomalous 'modern' date (XU20a, Square C) probably

Table 1 AMS radiocarbon ages (charcoal) for Squares $C$ and D, Bogi 1. * Median probability of calibrated dates rounded to the nearest 50 years.

\begin{tabular}{|c|c|c|c|c|c|c|c|}
\hline Lab. Code & Square & $\begin{array}{c}\text { XU } \\
\text { (Sample \#) }\end{array}$ & $\begin{array}{l}\text { Depth } \\
\text { (cm) }\end{array}$ & $\begin{array}{l}\delta^{13} \mathrm{C} \% \\
( \pm 0.2)\end{array}$ & $\begin{array}{c}{ }^{14} \mathrm{C} \text { Age } \\
\text { (years BP) }\end{array}$ & $\begin{array}{c}\text { Calibrated } \\
\text { Age BP } \\
\text { (95.4\% } \\
\text { probability) }\end{array}$ & $\begin{array}{c}\text { Calibrated } \\
\text { Age BP } \\
\text { (circa*) }\end{array}$ \\
\hline Wk-28266 & $\mathrm{C}$ & $6(2)$ & 11.0 & -26.7 & $1603 \pm 30$ & $1411-1548$ & 1500 \\
\hline Wk-28267 & C & $8(2)$ & 13.8 & -25.0 & $1599 \pm 30$ & $1410-1545$ & 1450 \\
\hline Wk-28268 & $\mathrm{C}$ & $11(3)$ & 22.0 & -27.1 & $1537 \pm 30$ & 1359-1518 & 1450 \\
\hline Wk-30458 & $\mathrm{C}$ & $15 a(1)$ & $28.3-30.5$ & -24.5 & $2090 \pm 25$ & 1994-2128 & 2050 \\
\hline Wk-29210 & C & $17 a$ & $33.3-36.2$ & -23.8 & $2148 \pm 32$ & $2006-2305$ & 2150 \\
\hline Wk-29211 & $\mathrm{C}$ & $20 a$ & $40.3-43.0$ & -14.9 & $105.8 \pm 0.4 \%$ & modern & modern \\
\hline Wk-28270 & $\mathrm{C}$ & $24 a(3)$ & 53.0 & 0.0 & $2147 \pm 30$ & $2007-2304$ & 2150 \\
\hline Wk-28271 & $\mathrm{C}$ & $29 a(2)$ & 65.4 & -25.2 & $2159 \pm 30$ & 2053-2307 & 2150 \\
\hline Wk-27500 & $\mathrm{C}$ & $36 a(1)$ & 84.4 & -28.4 & $2223 \pm 30$ & $2152-2332$ & 2250 \\
\hline Wk- 29953 & $\mathrm{C}$ & $53(1)$ & 116 & - & $2448 \pm 25$ & $2359-2700$ & 2500 \\
\hline Wk-29954 & $\mathrm{C}$ & $58(4)$ & 128 & -23.3 & $2508 \pm 25$ & $2488-2733$ & 2600 \\
\hline Wk-27713 & $\mathrm{D}$ & $60(2)$ & 132.8 & -24.6 & $2538 \pm 30$ & $2494-2746$ & 2650 \\
\hline Wk-27712 & $\mathrm{D}$ & $61(1)$ & 136.4 & -25.8 & $2537 \pm 30$ & $2494-2746$ & 2650 \\
\hline Wk-27711 & $\mathrm{D}$ & $63(1)$ & 142.5 & 0.0 & $2775 \pm 30$ & 2791-2949 & 2850 \\
\hline Wk-27707 & $D$ & $67 a(1)$ & 150.8 & -26.5 & $2783 \pm 30$ & 2793-2955 & 2900 \\
\hline Wk-30465 & $\mathrm{C}$ & $72(1)$ & 164.4-167.2 & -27.5 & $3491 \pm 25$ & $3695-3835$ & 3750 \\
\hline Wk-27710 & $\mathrm{D}$ & $74(1)$ & 169.7 & -22.5 & $2533 \pm 30$ & $2492-2745$ & 2600 \\
\hline Wk-29956 & $\mathrm{C}$ & $81(1)$ & 188 & -26.8 & $3667 \pm 25$ & $3914-4084$ & 4000 \\
\hline Wk-27708 & $\mathrm{D}$ & $84(1)$ & 194.1 & -25.1 & $3826 \pm 30$ & $4096-4406$ & 4200 \\
\hline Wk-28272 & $\mathrm{C}$ & $90(1)$ & 209.8 & -25.9 & $3824 \pm 30$ & $4095-4405$ & 4200 \\
\hline Wk-28273 & $\mathrm{C}$ & $93(2)$ & $215.7-218.1$ & 0.0 & $3811 \pm 30$ & $4089-4350$ & 4200 \\
\hline Wk-28274 & $\mathrm{C}$ & $100(1)$ & 233.2 & -24.2 & $3833 \pm 30$ & 4103-4406 & 4250 \\
\hline Wk-28275 & $\mathrm{C}$ & $104(1)$ & 242.3-244.5 & -25.4 & $3816 \pm 30$ & $4091-4382$ & 4200 \\
\hline Wk-28278 & $\mathrm{C}$ & $127(1)$ & 301.3 & -25.6 & $4053 \pm 30$ & $4428-4784$ & 4550 \\
\hline
\end{tabular}


reflects dating of light-weight plant material (e.g. grass) that inadvertently blew into the pit during excavation, a conclusion consistent with the $\delta^{13} \mathrm{C}$ value of $-14.9 \pm 0.2 \%$ o (Bender 1971). In contrast to most other carbon dates, this dated material was obtained from the sieves (it was not a 3D-plotted in situ sample), and came from the first XU excavated after the pit had been exposed for two days. Dates were determined by the University of Waikato Radiocarbon Dating Laboratory and calibrated into calendar years using the online calibration programme Calib 6.0 and the IntCal09 dataset (Reimer et al. 2009; Stuiver and Reimer 1993). Dates range from $1450 \mathrm{cal} \mathrm{BP}$ near the surface down to $4550 \mathrm{cal} \mathrm{BP}$ at a depth of $301 \mathrm{~cm}$. The series of dates is generally in chronological order with depth, suggesting little or no significant postdepositional disturbance of sediments. The three major midden concentrations date to c.2000-2150 cal BP (SUs 5-6), 2600-2900 cal BP (SU7B and lower 7A), and $>3000-4200 \mathrm{cal} \mathrm{BP}$ (upper SU8). At the top of the stratigraphic sequence, SUs 1-4 largely date to c. $1500 \mathrm{cal} \mathrm{BP}$ and seal the uppermost midden concentration of SUs 5-6 from later cultural activity. There is no archaeological or geomorphological evidence that the area of Bogi 1 was ever used for recent gardening activity, thereby avoiding this potential source of sediment disturbance often problematic at other Pacific Lapita sites. Occupational continuity between the upper two midden concentrations is indicated by intervening radiocarbon dates and cultural materials, including pottery evidencing the in situ transformation of design conventions through time. In contrast, little activity, and possibly an occupational hiatus exists between the two lower midden concentrations.

\section{Pottery}

The deepest 3D-plotted sherd at Bogi 1 lying flat in original depositional context comes from a depth of $154 \mathrm{~cm}$ (Square C) dating to $2900 \mathrm{cal} \mathrm{BP}$. Between $155 \mathrm{~cm}$ and $127 \mathrm{~cm}$ below the surface in Squares $C$ and $\mathrm{D}$ a total of 32 pottery sherds were plotted in $3 \mathrm{D}$, revealing the earliest unambiguous presence of pottery at the site. Of these, 14 sherds were lying flat, suggesting strongly that they are in situ and have undergone little if any post-depositional movement/ disturbance. Similarly, a concentration of

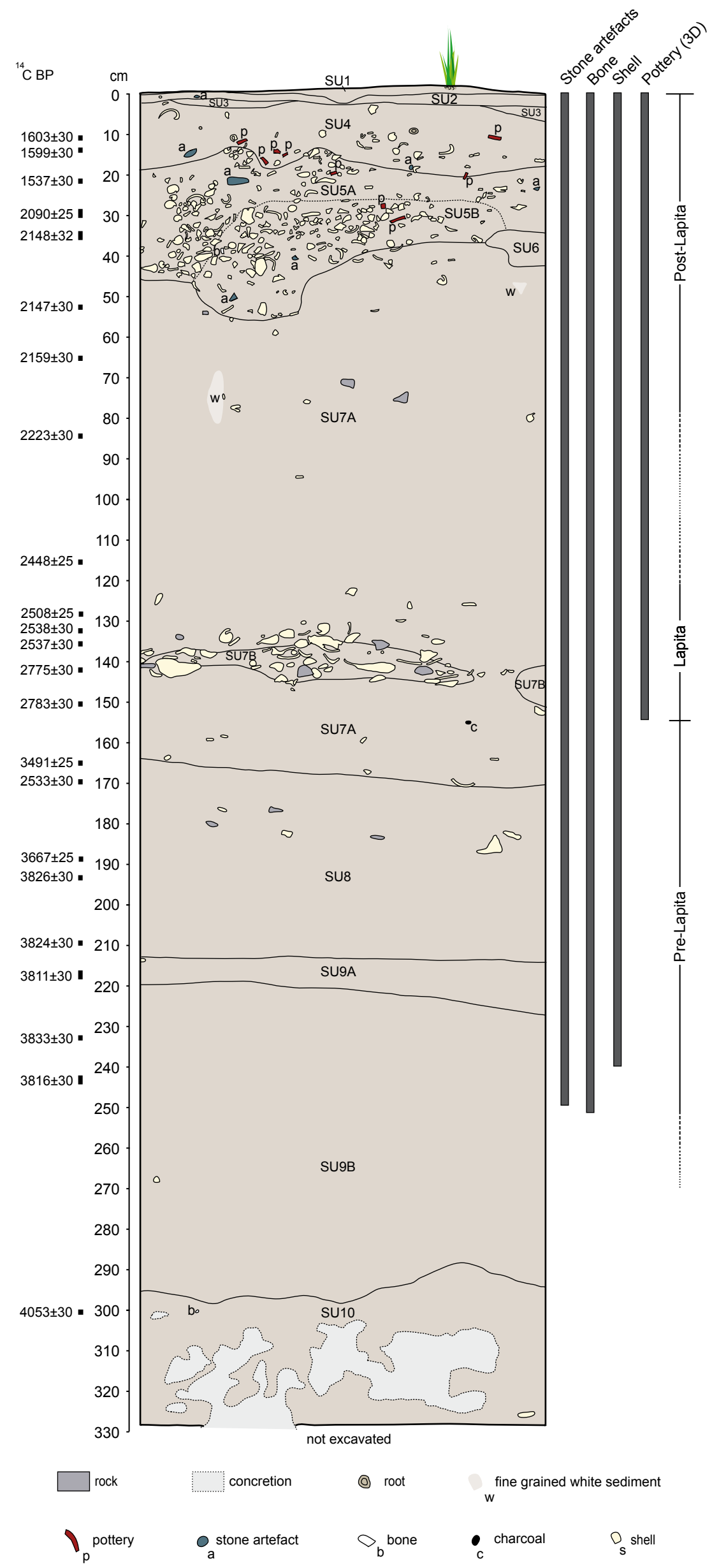

Figure 3 Stratigraphy of Square D, Bogi 1. 


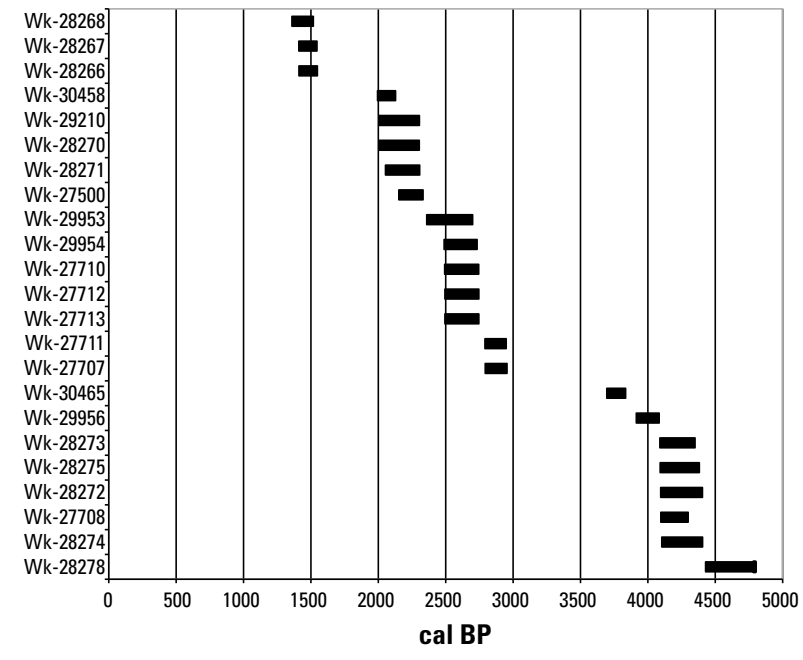

Figure 4 AMS radiocarbon dates (calibrated $95.4 \%$ probability range) for Squares C and D, Bogi 1 (excluding anomalous modern date).

over 20 3D-plotted sherds lying flat and deriving from a single pot was recovered from Square F (located next to Square D) between $140 \mathrm{~cm}$ and $150 \mathrm{~cm}$ below the surface. These two groups of more than 50 sherds date to between 2600 and $2900 \mathrm{cal} \mathrm{BP}$. Given pottery sherds are found throughout the upper $155 \mathrm{~cm}$ of deposit, pottery use at Bogi 1 dates from 2900 cal BP to 2000 cal BP.

Comb dentate-stamped Lapita pottery dates from 2900 cal BP and gives way to sparsely-decorated, shell valve endimpressed curvilinear designs and structurally simple geometric comb dentate-stamped designs below the lip sometime between 2500 and $2250 \mathrm{cal} \mathrm{BP}$, which then give way to shell valve endimpressed dentate designs. Lapita pottery is represented by a range of vessel shapes including low-fired, thick-walled carinated and sometimes collared vessels, but no flat-bottomed vessels are present. Decoration includes comb dentate (including needlepoint as well as relatively broad-tined) stamping and redslipping. Incised designs are virtually absent. A common theme that characterises the Caution Bay Lapita sites is impressed parallel (usually paired) sets of single-curve impressions made with a narrow tool (sometimes tined, sometimes continuousedged) repeated in various combinations across the upper part of pots (Figure 5). A single comb-impressed, shallow cylinder stand fragment has been found, indicating that unlike the situation further to the northeast, cylinder stands are rare. The face design typically found in other Lapita regions is entirely absent.

\section{Food Remains}

The Caution Bay Lapita peoples were characteristically 'harvesting the sea' (Kirch 1997, 2010). Sites reveal exploitation of over 130 species of shellfish (e.g. Anadara spp., Gafrarium spp., Ostrea spp., Pinctada spp., Strombus spp. and Cerithidea spp.) from a range of sandy, rocky and muddy intertidal habitats. Other marine foods include reef-dwelling parrotfish (Scaridae), wrasse (Labridae), sea urchin and crab, with marine hunting using canoes indicated by bones of marine turtle (probably Chelondia mydas). Catfish (Ariidae) bones reveal exploitation of estuarine/ freshwater habitats. Marine subsistence was supplemented by terrestrial fauna, in particular macropods (e.g. Macropus agilis). Like many Lapita sites, bird bones are rare.

\section{Shell and Stone Artefacts}

Typical of Lapita sites elsewhere (Szabó 2010), Caution Bay Lapita sites contain a variety of shell artefacts. Most common are ground, narrow rings (typical of Lapita armbands) made from cone shell (Conus sp.) and clam shell (Tridacna sp.); broad rings are also present but less common (Figure 6). Shell fishhooks, rare in Lapita sites more generally, are absent.

Stone artefacts in Caution Bay Lapita sites represent the familiar technological repertoire of ground stone (igneous) adzes and flakes (mostly unretouched) of chert and obsidian (e.g. Sheppard 2010). While chert is plentiful locally, adzes were probably imported from the mountainous hinterland while the nearest source of obsidian is West Fergusson Island located $500 \mathrm{~km}$ to the southeast (Irwin and Holdaway 1996). In Square C at Bogi 1, obsidian starts at XU53 (c.2500 cal BP) but only becomes a regular part of stone artefact assemblages after XU39 dating to c.2500-2250 cal BP. While importation and longdistance movement of obsidian is a key dimension of Lapita exchange systems (Summerhayes 2009), at Caution Bay obsidian use dates to the end of the Lapita period and is more a feature of post-Lapita assemblages, as has been found elsewhere along the southeast Papuan coast (Irwin and Holdaway 1996; Allen et al. 2011).

\section{Pre-Lapita Burial}

A flexed human burial was recovered from pre-ceramic cultural deposits at a depth of $195 \mathrm{~cm}$ at Bogi 1 (Figures 2, 7). The burial was associated with shell grave-goods (e.g. Pinctada sp., Tridacna sp.) grouped into two clusters located on the left and right side of the body. The absence of pottery in the grave fill suggests strongly that the burial is pre-ceramic in age and thus dates to before 2900 cal BP. As the burial pit was excavated into sediments dating to $4200 \mathrm{cal} \mathrm{BP}$, the burial is bracketed in age between 2900 and 4200 cal BP. More precise dating will need to await the results of direct radiocarbon dating of human bone. Whatever the case, these remains represent the first complete human burial recovered from beneath Lapita levels in the Pacific.

Food remains (shells and bones of fish and turtle) in the lower levels of Bogi 1 and JD6 confirm that pre-Lapita peoples of Caution Bay were marine specialists similar to subsequent Lapita peoples. Shell grave-goods indicate this maritime economic orientation extended to the ritual realm. Ground-stone adzes indicate similar continuities, including fully-ground adzes dating to c. $4200 \mathrm{cal} \mathrm{BP}$.

\section{Conclusions}

The Caution Bay Lapita sites have overturned decades of archaeological orthodoxy which characterised Lapita as an exclusive phenomenon of Island Melanesia but not mainland New Guinea. It is now clear that Lapita colonisers moving out of the Bismarck Archipelago not only moved eastwards into the Pacific but also south and then westwards along the Papua New Guinea south coast. The presence of Lapita at Caution Bay at $2900 \mathrm{cal} \mathrm{BP}$ is synchronous with the Lapita colonisation of Remote Oceania 3000-2900 cal BP. Unlike Remote Oceania, however, pre-Lapita occupation at Bogi 1 and JD6 indicates that Caution Bay Lapita peoples colonised a previously settled coastline. As with the significant issue of the Lapita/pre-Lapita boundary in the Bismarcks (Specht 2009), the extent to which 
A

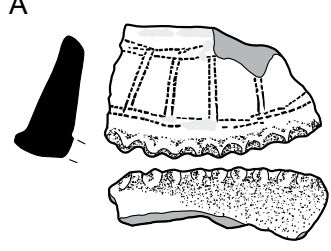

B

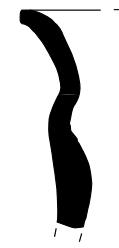

E

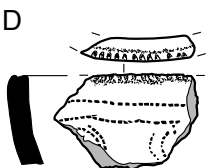

D

$\mathrm{H}$

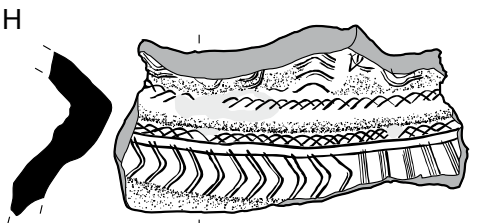

$\mathrm{L}$

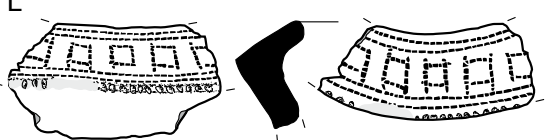

I

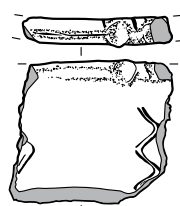

M

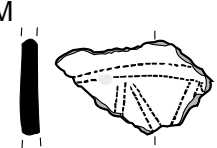

C

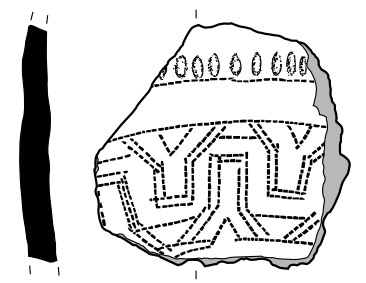

G

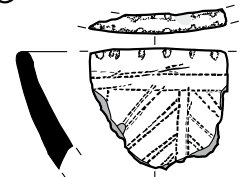

$\mathrm{K}$

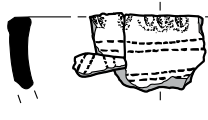

$\mathrm{N}$

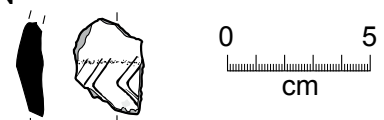

Figure 5 Lapita pottery from Caution Bay dating between 2900 and 2500 cal BP. A, B, F, G, K, L, M: site Bogi 1; C, D: site Moiapu 1; E, H, I, J: site JD6 and N: site JD17.

an occupational hiatus exists at this boundary at Caution Bay remains to be determined. Whatever the case, Caution Bay provides a unique opportunity on a landscape scale to explore the extent to which Lapita settlement was a negotiated process of social interaction and accommodation.

The ensemble of Lapita sites at Caution Bay spanning at least 400 years indicates a locally-viable Lapita community and not simply Lapita transients. Unprecedented in most other Lapita contexts, the Caution Bay sites provide an opportunity to examine localised Lapita village differentiation and interaction on a landscape scale, in addition to more conventional investigations of long-distance exchange networks. Most significantly, more than 1200 years of continuous occupation and ceramics from Lapita into the period of the earliest hitherto-documented evidence of ceramics along the south coast of mainland Papua New Guinea, followed by the presence of later ceramics, provides a unique opportunity to understand both Lapita transformations on a landscape scale and the origins and development of later ceramic assemblages leading into the ethnographic period (Allen et al. 2011).

Finally, the presence of Lapita peoples on the southern New Guinea coast at $2900 \mathrm{cal}$ BP raises the question of the western limit of these migrating peoples. Pottery dating back to c. $2500 \mathrm{cal}$ BP in Torres Strait located $500 \mathrm{~km}$ west of Caution Bay suggests influences from the Papua New Guinea mainland and/or from long-distance seafaring ceramicists. While recent DNA analyses found no recent Melanesian intrusions into Aboriginal Australia (Hudjashov et al. 2007), such conclusions are premature given analytical exclusion of relevant DNA samples from northeast Australia. The presence of pottery-bearing Melanesian peoples on Australia's doorstep allows hypotheses for Melanesian cultural influences down the Australian east coast over the past 3000 years (Barham 2000; Barker 2004:148) plausibly to include genetic transfers and even migration.

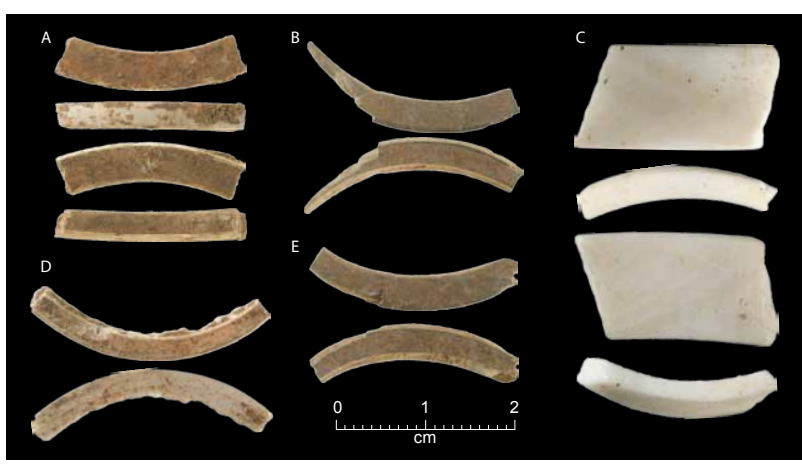

Figure 6 Lapita shell artefacts from Caution Bay dating to c.2600-2500 cal BP. A: site Moiapu 1; B: site JA1; C: site JD14; D: site Moiapu 1; E: site JA1 (Photograph: Steve Morton).

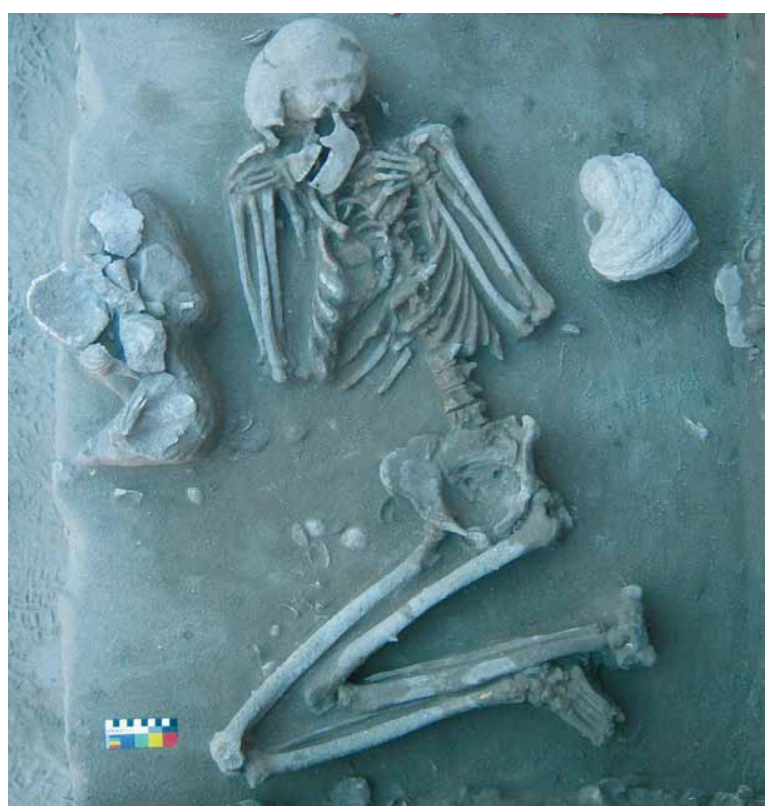

Figure 7 Pre-Lapita burial dating to between 2900 and 4200 cal BP, Bogi 1 (Photograph: Ian J. McNiven). 


\section{Acknowledgements}

Thanks to Helene Tomkins, Janet Sypkens, Judy Smith, Jacqueline Matthews and Amber Kimber for assistance with shell analyses. Helpful comments on this paper were kindly provided by Ian Lilley, Glenn Summerhayes, Peter Veth and anonymous referees.

\section{References}

Allen, J., G. Summerhayes, H. Mandui and M. Leavesley 2011 New data from Oposisi: Implications for the Early Papuan Pottery phase. Journal of Pacific Archaeology 2(1):69-81.

Barham, A.J. 2000 Late Holocene maritime societies in the Torres Strait Islands, northern Australia - Cultural arrival or cultural emergence? In S. O'Connor and P. Veth (eds), East of Wallace's Line: Studies of Past and Present Maritime Cultures of the Indo-Pacific Region, pp.223-314. Modern Quaternary Research in Southeast Asia 16. Rotterdam: A.A. Balkema.

Barker, B. 2004 The Sea People: Late Holocene Maritime Specialisation in the Whitsunday Islands, Central Queensland. Terra Australis 20. Canberra: Pandanus Books.

Bedford, S., M. Spriggs and R. Regenvanu 2006 The Teouma Lapita site and the early human settlement of the Pacific Islands. Antiquity 80:812-827.

Bender, M.M. 1971 Variations in the ${ }^{13} \mathrm{C} /{ }^{12} \mathrm{C}$ ratios of plants in relation to the pathway of photosynthetic carbon dioxide fixation. Phytochemistry 10:12391244.

Burley, D.V. and S.P. Connaughton 2007 First Lapita settlement and its chronology in Vava'u, Kingdom of Tonga. Radiocarbon 49(1):131-137.

Clark, G. and A. Anderson 2009 Site chronology and a review of radiocarbon dates from Fiji. In G. Clark and A. Anderson (eds), The Early Prehistory of Fiji, pp.153-182. Terra Australis 31. Canberra: ANU E Press.

Green, R. 1979 Lapita. In J.D. Jennings (ed.), The Prehistory of Polynesia, pp.27-60. Canberra: ANU Press.

Green, R.C., M. Jones and P. Sheppard 2008 The reconstructed environment and absolute dating of SE-SZ-8 Lapita site on Nendö, Santa Cruz, Solomon Islands. Archaeology in Oceania 43(2):49-61.

Hudjashov, G., T. Kivisild, P.A. Underhill, P. Endicott, J.J. Sanchez, A.A. Lin, P. Shen, P. Oefner, C. Renfrew, R. Villems and P. Forster 2007 Revealing the prehistoric settlement of Australia by Y chromosome and mtDNA analysis. Proceedings of the National Academy of Sciences 104(21):8726-8730.

Irwin, G. and S. Holdaway 1996 Colonisation, trade and exchange: From Papua to Lapita. In J. Davidson, G. Irwin, F. Leach, A. Pawley and D. Brown (eds), Oceanic Culture History: Essays in Honour of Roger Green, pp.225-235. Dunedin: New Zealand Journal of Archaeology Special Publication.

Kirch, P.V. 1997 The Lapita Peoples. Cambridge: Blackwell.

Kirch, P.V. 2010 Between garden and reef: Lapita ecology and subsistence. In C. Sand and S. Bedford (eds), Lapita: Oceanic Ancestors, pp. 253-267. Paris: Musée Du Quai Branley.

Lilley, I. 2008 Flights of fancy: Fractal geometry, the Lapita dispersal and punctuated colonisation in the Pacific. In G. Clark, F. Leach and S. O'Connor (eds), Islands of Inquiry: Colonisation, Seafaring and the Archaeology of Maritime Landscapes, pp.75-86. Terra Australis 29. Canberra: ANU E Press.

McNiven, I.J., W.R. Dickinson, B. David, M. Weisler, F. von Gnielinski, M. Carter and U. Zoppi 2006 Mask Cave: Red-slipped pottery and the Australian-Papuan settlement of Zenadh Kes (Torres Strait). Archaeology in Oceania 41(2):49-81.

Negishi, Y. and R. Ono 2009 Kasasinabwana shell midden: The prehistoric ceramic sequence of Wari Island in the Massim, eastern Papua New Guinea. People and Culture in Oceania 25:23-52.

Reimer, P.J., M.G.L. Baillie, E. Bard, A. Bayliss, J.W. Beck, P.G. Blackwell, C. Bronk Ramsey, C.E. Buck, G.S. Burr, R.L. Edwards, M. Friedrich, P.M. Grootes, T.P. Guilderson, I. Hajdas, T.J. Heaton, A.G. Hogg, K.A. Hughen, K.F. Kaiser, B. Kromer, F.G. McCormac, S.W. Manning, R.W. Reimer, D.A. Richards, J.R. Southon, S. Talamo, C.S.M. Turney, J. van der Plicht and C.E. Weyhenmeyer 2009 IntCal09 and Marine09 radiocarbon age calibration curves, 0-50,000 years cal BP. Radiocarbon 51(4):1111-1150.

Rieth, T.M., A.E. Morrison and D.J. Addison 2008 The temporal and spatial patterning of the initial settlement of Sāmoa. Journal of Island and Coastal Archaeology 3:214-239.

Sheppard, P. 2010 Lapita stone tool technology. In C. Sand and S. Bedford (eds), Lapita: Oceanic Ancestors, pp. 241-251. Paris: Musée Du Quai Branley.

Specht, J. 2009 The aceramic to ceramic boundary in the Bismarck archipelago. In P.J. Sheppard, T. Thomas and G.R. Summerhayes (eds), Lapita: Ancestors and Descendants, pp.11-34. New Zealand Archaeological Association Monograph 28. Auckland: New Zealand Archaeological Association.

Spriggs, M. 1997 The Island Melanesians. Oxford: Blackwell.

Stuiver, M. and P.J. Reimer 1993 Extended ${ }^{14} \mathrm{C}$ database and revised CALIB radiocarbon calibration program. Radiocarbon 35:215-230.

Summerhayes, G.R. 2007 The rise and transformation of Lapita in the Bismarck Archipelago. In S. Chui and C. Sand (eds), From Southeast Asia to the Pacific: Archaeological Perspectives on the Austronesian Expansion and the Lapita Cultural Complex, pp.129-172. Taipei: Academia Sinica.

Summerhayes, G.R. 2009 Obsidian network patterns in Melanesia - Sources, characterisation and distribution. Bulletin of the Indo-Pacific Prehistory Association 29:110-124.

Summerhayes, G.R. 2010a Lapita interaction - An update. In M. Gadu and Hsiuman Lin (eds), International Symposium on Austronesian Studies, pp.11-40. Taitong: National Museum of Prehistory.

Summerhayes, G.R. 2010b The emergence of the Lapita cultural complex in the Bismarck Archipelago. In C. Sand and S. Bedford (eds), Lapita: Oceanic Ancestors, pp.93-101. Paris: Musée Du Quai Branley.

Summerhayes, G.R. and J. Allen 2007 Lapita writ small. In S. Bedford, C. Sand and S.P. Connaughton (eds), Oceanic Explorations: Lapita and Western Pacific Settlement, pp.97-122 Terra Australis 26. Canberra: ANU E Press.

Szabó, K. 2010 Shell artefacts and shell-working within the Lapita Cultural Complex. Journal of Pacific Archaeology 1:115-127. 